\title{
Modes of Regulation in the Governance of the European Union: Towards a Comprehensive Evaluation $(*)$
}

\begin{tabular}{|c||}
\hline \hline Christoph Knill and Andrea Lenschow \\
\hline \hline European Integration online Papers (EIoP) Vol. 7 (2003) $\mathrm{N}^{\circ}$ 1; \\
http://eiop.or.at/eiop/texte/2003-001a.htm
\end{tabular}

\section{Contents:}

- 1 Introduction

- 2 European Governance: A Typology of Regulatory Modes

○ 2.1 Forms of Intervention

- 2.2 Dominant Mechanisms of Steering

- 3 "Good Governance"? Evaluating the Different Modes of Regulation

○ 3.1 Decision-making Capacity

○ 3.2 Implementation Effectiveness

- 3.3 Problem-solving Capacity

○ 3.4 Democratic Legitimacy

- 4 Conclusion

- References

\section{Introduction}

Forms of governance are in transition on an international scale. Neither the juxtaposition of the market and state regulation nor that of public versus private actors in governing society match well with the multiple faces of modern governance. The classical regulatory state which has emerged as an alternative to the welfare state - both however with the intent to complement or correct market mechanisms - is gradually changing its distinctive face of top-down authoritative control of market and society and joining with other steering mechanisms(1). The process of regulating is being decentralised, allowing access to and spreading responsibilities across economic and societal actors; the regulations itself are taking on various forms ranging from substantive rules, incentives to procedural requirements; chains of control are blurring and mechanisms of control softening with the emphasis shifting towards more responsiveness and self-responsibility.

While this trend is a general one, the European Union (EU), which has been characterised as a regulatory state par excellence (Majone 1994), represents a particularly good example to investigate and evaluate it. As part of a larger governance debate in Europe, triggered by a declining competitiveness of the European economy globally, concerns with regard to the protection of citizens in an increasingly uncertain environment (characterised by rapid technological change as well as open borders, and the fading capacities of national states to cope with these challenges), the EU is experimenting with a variety of different regulatory approaches. Historically, the EU regulators were caught between functional needs and political pressures and hence, the EU regulatory apparatus developed ad hoc and in patchwork style. Nevertheless, we can observe the emergence of less authoritative, less interventionist, more participatory regulatory forms. 
The political system of the EU reveals several characteristics that are particularly favourable to engage in this development. Of particular importance in this respect is its nature as a multi-level system. The complex intermeshing of powers and competencies of public and private actors at varying institutional levels poses enormous challenges with respect to the accommodation of diverse interests in order to ensure the system's overall legitimacy, both in terms of input (democratic standards) and output criteria (decision-making, implementation, problem-solving). As a consequence, we observe a complex picture of coexisting and overlapping patterns of regulation both within and across different policy sectors.

Based on this observation, this chapter has two objectives. First, it is our aim to structure the complex picture of different modes of EU regulation. To arrive at a differentiated picture of the EU regulatory state, we develop a typology of different modes of European regulation ranging from classical legal instruments to softer forms of steering the economy and society (akin to Scott's concept of the (post-) regulatory state; in Scott 2003). In a second step, we are looking at the regulatory transition from a normative angle. Although the choice of regulatory instruments will always be the result of political processes shaped by interests, power as well as institutional constellations, the functionality of regulatory instruments in terms of policy outcome and societal impact is likely to enter the debate. This is true especially in the EU which continues to suffer from unstable support in the population as well as parts of the political elite. Hence, we analyse the various types of regulation employed in EU policy making on the basis of several evaluation criteria, offering a critical commentary on regulatory modes and trends.

\section{European Governance: A Typology of Regulatory Modes ${ }^{\uparrow}$}

In order to classify the varying patterns of regulation characterising European governance, we proceed in two steps. First, we look at different forms of intervention which emerge from the specific allocation of competencies within the multi-level system. In a second step, we attempt to develop this typology further by analysing the process set in motion through these forms of intervention; i.e., the steering mechanisms by which the intended policy objectives shall be achieved.

\subsection{Forms of Intervention}

Considering that we are dealing with the EU, we need to pay particular attention to the multi-level structure framing regulatory processes. This institutional context forces us to consider the distribution of responsibilities across regulatory centres (such as the EU, national executives or nonstate actors). We therefore focus on two dimensions of regulatory intervention: the level of obligation and the level of discretion. EU regulatory policy may differ in terms of its obligatory nature imposed on its addressees, hence the level of legal authority associated with EU intervention. In addition, EU regulatory policy may differ with respect to the distribution of tasks across the levels of governance and the level of discretion they grant to decentralised actors in the implementation process. While both dimensions may apply to regulatory approaches in general, they are particularly central in the evolution of the EU regulatory state.

The following table summarises the mix of regulatory patterns that currently co-exists in the EU. Combining the two dimensions of regulation - obligation and discretion - we arrive at four modes of intervention. In the table we identify those classes of regulatory instruments that are representative for each mode(2). 
The substantive and procedural regulatory standards fit the image of the EU regulatory state - and true enough, these regulatory instruments remain the dominant form of intervention in the European single market and other spheres of social life (cf. Héritier 2002; Holzinger, Knill and Schäfer 2003). Regulatory standards usually entail obligatory and detailed rules, allowing the EU Commission - at least in theory - to control the level of compliance on the national and regional level (Baldwin and Cave 1999, 160). Concentrating on both standard setting and legal control at the supranational level, this is the most hierarchical (top-down) mode of regulation.

The so-called new instruments are a mixed bag of regulatory tools(3). What they have in common is a more indirect approach towards achieving behavioural change. While the level of obligation for the national administration is high, the addressees of these policy instruments have broad leeway to comply within a relatively open regulatory space (framework regulation) or to react to new procedural or incentive structures (economic and communicative instruments).

Framework regulations leave it to decentralised levels of governance to add regulatory substance fitting local conditions into the European framework defining obligatory general guidelines and goals (Baldwin and Cave 1999, 161). Economic and communicative instruments have been designed to target the problem perception and incentive structures of economic and social actors. Instead of hierarchy, these regulations emphasise participation, self-initiative, and voluntarism. Procedural requirements are meant to contribute to achieving substantive objectives (cf. Knill and Lenschow 2000).

The instruments listed in the second row of the table shift regulatory responsibility away from the EU level to private actors or national authorities. The self-regulatory model is based on private actors devising concrete regulatory standards - in the shadow of the state. Typically, an industrial association (as opposed to government or firm) sets rules and standards (codes of practice) for the conduct of the associated firms (Gunningham and Rees 1997, 365). The level of control shifts from EU to the industry-level, although the failure to self-regulate may trigger the return to the regulatory standards approach.

In the EU, private self-regulation can be observed in two basic forms. First, self-regulation is based on voluntary agreements between the Commission and sectoral associations. In these agreements (which officially are declared as Commission recommendations), industry commits itself to the implementation of certain requirements. A second pattern can be observed in the field of social policy. Based on the Social Protocol of the Maastricht Treaty the Commission is not only legally required to consult the European peak associations of industry and trade unions before developing social policy proposals. The member states have also accepted that negotiations between these associations can serve as a substitute for traditional European regulatory processes (Falkner 2000). The final agreement of the corporatist partners, however, takes the traditional form of an EU directive.

While all types discussed to far have to do with rules to be followed, the $O M C$ follows a mere process model. While certain policy benchmarks are set for the Union, national responses are formulated independently and without the threat of formal sanctions. The EU merely provides a context and enabling structures for cooperation and learning among national policy makers. The regulatory impact of this approach rests on dissemination of best practice and the provision of incentives (peer review) rather than legal obligation and control. Hence, the level of obligation to a regulatory centre is low and a wide range of policy strategies to achieve general EU targets could be chosen. 


\subsection{Dominant Mechanisms of Steering}

Each regulatory type implies a different mechanism of policy adaptation on the national level and hence, also a different model of governance in the European multi-level system. We can distinguish three general mechanisms through which regulators might seek to affect the behaviour of the regulated: (a) they may be coerced to comply with the regulation, (b) they may be "tempted" to change their behaviour due to incentive effects of the regulation and (c) they may learn, i.e. redefine their interests on the basis of new knowledge gathered due to the regulatory context and subsequently adapt their behaviour. As most regulatory instruments are characterised by various mechanisms, we developed a ranking. In table 2 we distinguish between three levels of relevance ( ++ dominant mechanism; + relevant mechanism; 0 irrelevant mechanism). In assessing the relative importance of steering mechanisms, the analytical focus is on the underlying intentions of the regulators rather than the actual performance or "objective" relevance of these mechanisms.

\section{Table 2}

We argue that different types of regulations entail different models of governance. The early European regulatory state relied primarily on the hierarchy model with its implied powers of coercion. This model makes no attempt to influence the awareness of the addressees of the problem structure by either tackling strategic or cognitive foundations of individual behaviour.

The new modes depart from the hierarchical model to different degrees. The least radical departure leads to the application of new instruments. This public delegation model relies on an authoritative framework, but places particular emphasis on creating incentive structures at the EU level and leaving discretionary space for lower levels of governance to add the relevant administrative procedures. The widespread inability or unwillingness of lower level administrative agents to implement detailed EU regulation has been one reason for experimenting with such softer instruments.

A more far-reaching departure from the hierarchical model of regulation is the delegation model based on private self-regulation (Black 1996; Ogus 1995). The EU calls especially on economic actors to form a private network in order to solve particular problems collectively. The private network is responsible for setting regulatory standards and for ensuring compliance. The dominant mechanism leading to behavioural change relies on the provision of incentives as the self-regulatory approach induces economic actors to comply with rules formulated "in their name" and in view of their needs and capacities. Nevertheless, it is important to note that this model generally exists with a "fall-back regulatory option", i.e. in conjunction and in the shadow of the hierarchical state.

Moreover, learning effects among the members of the private network constitute a supplementary steering mechanism.

Finally, the most fundamental departure from the hierarchy model is the OMC. Here, hierarchy does not even feature as a fall-back option. Regulatory responsibility is entirely located at the national level (where the hierarchical model may still apply, however), hence the notion of radical subsidiarity (cf. Hodson and Maher 2001). The EU assumes a completely new governance function in facilitating coordination and mutual learning among national policy elites. There is no formal attempt to control outcomes, although the method is dependent on the prior agreement on general principles and goals in the policy area in question (de la Porte and Pochet 2002; Scott and Trubek 2002). Moreover, hierarchical elements in terms of reporting requirements and the reliance on incentive structures (peer pressure) are complementary steering mechanisms that stimulate learning and diffusion processes. 


\section{3 "Good Governance"? Evaluating the Different Modes of Regulation $^{\uparrow}$}

To decide whether a certain mode of regulation reflects "good governance" or not, we need to be clear about the benchmarks of such an evaluation (cf. Baldwin 1995; Baldwin and Cave 1999, 76). When considering the current political and scientific discussion on "good governance" in the EU, it becomes obvious that these criteria are debatable. The main conflict deals with the question whether either input or output legitimacy of European regulation should serve as primary evaluation criteria (Scharpf 1999).

Traditionally, output factors constitute the major focus of legitimising EU regulatory policy. Particular attention is paid to three factors: (1) the extent to which the EU has the capacity of taking political decisions in a certain area; (2) the extent to which these decisions are actually implemented and complied with at the national level; and (3) the degree to which the policies in question achieve their intended objectives (problem-solving capacity). The concern with these factors can be traced to the nature of the EU political system, where high consensus requirements in the decision-making process and lacking powers of hierarchical intervention during the implementation stage constitute far-reaching problems for efficient and effective governance.

The intensive concern with decision-making and implementation diverted attention from questions of input legitimacy. While this narrow evaluative base did fit the technocratic image of the EU as an institution established to deal with problem-solving deficiencies of the nation state, it is inadequate once we consider the EU as a new polity or system of governance. With the waning acceptance of EU policy-making among the European citizens in recent years, the democratic quality of the EU has finally taken up in the academic debate on EU governance (cf. Abromeit 1998; Zürn 1996).

The recognition of this multiple legitimisation challenge among EU policy makers is visible not only in the publication of the White Paper on Governance, but also in the general regulatory practice as described above. A general analysis of the merits of different regulatory modes with respect to the various normative criteria has not been performed so far. In the following, we will attempt therefore such an evaluation(4). Of course, we acknowledge that the actual politics of regulatory choice is only partially normatively driven, but the result of multiple interests interacting in a complex institutional setting. Nevertheless, the present existential debates within the EU open windows of opportunity for normative evaluation to influence future policy making.

There are certain limits to such evaluation: We will not weigh the relative significance of the individual performance indicators because in our view such weighing depends on the particular policy context as well as individual (or cultural) preferences. Hence, we do not claim to develop a final rank order of regulatory approaches in this paper; rather we try to develop a general template for assessing the potential of EU policy in light of particular circumstances. Only knowledge of the circumstances will enable the regulator to make choices with respect to potential trade-offs between two performance criteria. Notwithstanding these problems of evaluation, we think that much can be said for trying to assess regulatory performance. We will get an idea to what extent (and at what costs) the shift from the hierarchical mode of regulation towards alternative forms of EU intervention may actually result in an overall improvement of regulatory performance. Furthermore, we will gain some insights on the question to what extent a certain regulatory approach can be significantly improved on one of the four criteria without substantive loss on another. In other words, we are able to compare the relative strengths and weaknesses of different regulatory approaches with respect to their input and output legitimacy. 


\subsection{Decision-making Capacity ${ }^{\uparrow}$}

A necessary, albeit not sufficient, condition for effective regulation is the capability of governments to take a regulatory decision (or to enact a legislative mandate). This capacity can hardly be taken for granted, but varies across different political systems, depending on the specific institutional rules characterising the decision-making process. With respect to the EU, especially Scharpf (1999) emphasised far-reaching structural deficits in this regard, given the high consensus requirements in the Council. Although this view is not uncontested in the literature (cf. Benz 1998; Héritier, Knill and Mingers 1996), there seems to be a general agreement that decision-making at the European level is a demanding process, that, in many instances, requires the use of "subterfuges" (Héritier 1999) in order to escape from deadlock.

This general statement needs to be differentiated, however. Scharpf (1997) developed an important distinction between product and process standards (see also Holzinger 2001). Moreover, as will be argued in the following, the decision-making capacity of the EU multi-level system also varies with the underlying mode of regulation.

More precisely, there exists a close linkage between this capacity and respective levels of discretion and obligation implied by different modes of regulation. Quite obviously decision-making capacity decreases if the level of regulatory discretion goes down. The challenges to reach a consensus in the Council rises the more EU policies are based on very detailed regulatory arrangements, significantly constraining the options of national governments and authorities or private actors for adjusting to EU requirements. At the same time, the task to achieve an agreement between heterogeneous national interests increases with the extent to which regulatory requirements impose legally binding obligations on the decision makers.

Consequently, the ability to reach decisions can be expected to be lowest, if the EU adopts the model of hierarchical intervention by regulatory standards. As outlined above, this approach typically implies the prescription of rather detailed and legally binding requirements which have to be implemented and enforced by the member states. At first glance, this finding is in sharp contrast with the high number of regulatory standards which still constitute the dominant form of European regulation. This tendency, however, is basically the result of the member states' general consensus towards the establishment of a common market which is based on harmonised national rules and standards. On the other hand, this "permissive consensus" in favour of harmonisation varies across policy areas and problem types. With respect to market-making regulations and product standards the adoption of regulatory standards is more likely than in fields of market-shaping regulations defining requirements for national production and process standards (Scharpf 1997). Against this backdrop, it is hardly surprising that the Commission has increasingly experimented with other modes of regulation in order to overcome potential deadlocks in decision-making (Knill and Héritier 1996).

In sharp contrast with the regulatory standards approach, decision-making is relatively unproblematic in the OMC case. Agreement on benchmarks and guidelines between the member states is facilitated by the fact that they enjoy broad leeway in achieving these rather general and non-obligatory objectives. The relatively frictionless decision-making might explain why this mode of regulation is of particular importance in areas where the hierarchical approach of regulatory standards turned out to be highly ineffective such as social or home affairs policy (Working Group 2001).

The performance of the remaining modes of regulation (new instruments and private self-regulation) 
can be located in between the extreme poles defined by regulatory standards and OMC. In the case of new instruments, a mixed account emerges from the fact that they generally define broad, but nevertheless legally binding requirements. While considerable discretion for domestic compliance places them close to the $\mathrm{OMC}$, their obligatory nature underlines their proximity to regulatory intervention. In the end, the decision-making dynamics depend on the specific mixture of hierarchical and non-hierarchical elements in the Commission proposal, which might vary from case to case. Thus, in the case of economic and communicative instruments it can often be observed that substantive discretion (in terms of goal attainment) coincides with highly detailed procedural rules, limiting the member states' actual implementation choices. Such rules apply typically to consultation requirements, reporting obligations, and transparency concerns (Knill and Lenschow 2000; Scott and Trubek 2002). In the case of framework regulation, by contrast, non-hierarchical elements seem to play a more important role. Although framework directives may be combined with more detailed daughter directives, which tend to resemble the classical approach of hierarchical intervention, they exemplify flexible and differentiated forms of regulation in so far as they do not assume uniform national responses (Baldwin and Cave 1999, 161).

Evaluating decision-making of private self-regulation, we arrive at a similarly ambiguous judgement, albeit for different reasons. On the one hand, self-regulatory arrangements are based on voluntary agreements in the private sector which should generally facilitate the establishment of such regimes. On the other hand, the low level of discretion characterising this approach might reduce industry's preparedness to engage in self-regulation because the detailed prescriptions may impact unevenly on the relative competitiveness of industrial actors. It has been argued that these problems of decisionmaking disappear as soon as self-regulatory regimes are placed in "the shadow of hierarchy" (i.e. the threat of hierarchical intervention in case of non-agreement), because industry generally prefers selfregulation over top-down regulatory standards. For reasons outlined above, the EU's decisionmaking capacity in the case of regulatory standards is itself rather low; hence, the effect of the legislative threat can hardly be taken for granted when it comes to the establishment of selfregulatory arrangements.

In sum, the analysis indicates that the capacity to decide regulatory norms in the EU multi-level system varies considerably across different modes of regulation. More specifically, decision-making capacity linked to the OMC clearly exceeds that of regulatory standards, while the performance of new instruments and private self-regulation lies somewhere in between these poles.

\subsection{Implementation Effectiveness}

Effective regulation not only dependents on legislative decisions, but also on the extent to which these decisions are actually implemented and complied with. Generally member states or private actors have to take the necessary steps in order to fulfil the objectives spelled out in European legislation or industrial agreements in both formal and practical terms (cf. Knill and Lenschow 2000). To what extent do the four regulatory modes under investigation differ with respect to these aspects? At first glance, it seems to be rather difficult to identify significant differences. This can be traced to two factors.

First, there are problems of equal relevance for all four approaches (cf. Baldwin and Cave 1999, 56). For instance, the practice of "creative compliance"; i.e., the practice of avoiding the intention of a law without breaking the terms of the law, constitutes a common problem for all modes of regulation (cf. Cohn 2002; McBarnet and Whelan 1991). Second, not all regulatory characteristics in our classification have clear implications for implementation performance. This holds true in particular for the dimension of regulatory discretion. On the one hand, there are numerous studies emphasising 
the advantages of high discretion in terms of effective implementation, as it offers more leeway to adjust regulatory requirements to the social and political conditions at the national or subnational level (Lipsky 1980; Berman 1980). Other studies, by contrast, emphasise that highly specified rules provide a more promising basis for effective enforcement, since they define clear objectives and requirements for both implementers and addressees (Krämer 1992; Lübbe-Wolff 1996). Considering this trade-off between broad and detailed legal requirements, the level of discretion constitutes no useful indicator for explaining variances in the implementation performance of the different regulatory approaches.

We focus therefore on those dimensions where the impact on implementation is less ambiguous, namely the level of obligation and the underlying steering mechanisms. Concerning the first, it is generally argued that highly obligatory regulation has a higher potential for effective implementation, as the force of law can be used to impose the fixed standards or objectives (Baldwin and Cave 1999, 35). In the absence of legally binding requirements, by contrast, this "push-factor" is lacking and compliance rests solely on the "goodwill" of the implementers. Hence, from this perspective the obligatory approaches (regulatory standards and new instruments) achieve a higher ranking than non-obligatory approaches (private self-regulation and $\mathrm{OMC}$ ).

However, the level of obligation is not the only factor affecting the implementation of regulatory approaches. Of similar importance are "pull-factors"; i.e., aspects which influence the willingness of implementing bodies and policy addressees to comply with European requirements. In this context, the underlying steering mechanisms by which regulatory objectives shall be achieved are of crucial importance. Thus, we follow the argument that steering mechanisms that are responsive to the motivations and interests of implementers and the regulated actors contribute that the regulation in question is implemented effectively. Analysing the different modes of regulation from this perspective, we find that such responsive mechanisms are particularly relevant with respect to OMC and, although a little less, to new instruments. In the latter case, responsiveness emerges from the fact that new instruments explicitly seek to change incentive structures of the involved actors in order to stimulate and modify the domestic policy context in favour of effective compliance. Typical examples are economic incentives or participation and information rights. Incentives are also the steering logic behind the peer review of national policy developments in the context of the OMC. Moreover, the OMC promotes processes of coordination and mutual learning across national policymakers.

Regulatory standards do not explicitly attempt to alter strategic opportunities or stimulate mutual learning processes among implementers and the addressees of regulation. Their primary steering mechanism is coercion; behavioural adjustment is to be achieved by hierarchical means of command and control.

At first sight, private self-regulation seems to rely positively on pull factors as the incentive to escape top-down regulations induces private regulators to formulate and comply with own rules. This incentive depends on the presence of a coercive threat, however. If the shadow of the hierarchy is perceived weak, industry may respond to the opposite incentive to cheat. Private actors might implement regulatory rules in a rather light-handed way as the threat of enforcement or later topdown intervention in case of self-regulatory failure is low (Baldwin and Cave 1999, 58).

Summing up this discussion on implementation performance, new instruments emerge as the most promising approach. They combine a high degree of obligation with an explicit orientation to alter domestic incentive structures in favour of effective compliance; they rely on both sticks and carrots. In the case of private self-regulation, by contrast, the effectiveness of the carrot depends on the stick 
component, which in the EU is not well developed, suggesting a high likelihood of implementation deficits. Regulatory standards and the OMC reveal mixed patterns, indicating a medium ranking. While the obligatory nature might positively affect the implementation of regulatory standards, their non-responsiveness towards the domestic context constitutes a major source of implementation failures. Exactly the opposite constellation can be found with respect to the OMC. Here, the emphasis on mutual learning and coordination might have very positive effects, while the voluntariness implies that there is little external push driving and guiding domestic activities.

\subsection{Problem-solving Capacity}

Even if we assume that regulatory policy is implemented effectively, this does not guarantee that it actually achieves its objectives; effective decision-making and implementation are not sufficient to ensure effective problem-solving. For once, it is a common phenomenon that - due to high scientific uncertainty and complexity - regulators have no full understanding of the causal mechanisms behind a given problem. Furthermore, regulators might well know how an effective regulatory approach should be designed, but lack the power and resources to carry their views through the decisionmaking process. In both scenarios, the regulatory design may be inappropriate for coping with the problems at hand. In view of this constellation, two questions are being addressed in this section. First, we ask which factors might influence the quality of regulatory design. Second, we analyse the extent to which these factors are present or absent in the different modes of European regulation.

With regard to the general aspects which affect the quality of regulatory design, four factors are of particular importance. First, high adjustment flexibility allows for swift redesign of regulations in light of technological innovations, new scientific evidence or experience with former approaches. Second, it makes a crucial difference for effective goal attainment whether regulators design their rules in view of the interests of the public at large or in the interests of the regulated group/industry (problem of capture) (Mitnick 1980). Third, the problem-solving capacity can be expected to increase with the extent to which the regulatory design is responsive to different national and subnational problem constellations. Fourth, it constitutes an essential requirement for effective regulation that regulators have clear indicators in order to develop sound predictions on potential regulatory outcomes (Baldwin and Cave 1999, 43).

The following table shows that the different regulatory approaches under investigation reveal considerable differences with respect to these factors. They can be traced mainly to their distinctive characteristics in terms of obligation, discretion and dominant steering mechanisms.

\section{Table 3}

Opportunities for flexible adjustment are closely linked to the level of obligation. Adjustment is particularly difficult when regulation is based on legally binding directives (regulatory standards and new instruments). The complex procedures characterising EU policy-making and the need to accommodate a high diversity of interests turn the development of European legislation generally into a lengthy and cumbersome process. Since most changes of existing legislation require a new legislative decision, flexible responses in light of new regulatory, scientific or technological developments are difficult.(5) Flexible adjustment is much easier in cases where EU regulation is based on less demanding procedures. This applies in particular to the voluntary approaches of private self-regulation and the OMC.

The extent to which regulatory decisions suffer from capture problems is affected by the level of discretion inherent to the different approaches. Generally, capture is more likely in cases of highly 
detailed regulation. In such constellations, regulators require a high amount of information in order to carry out their task. As the regulated industry itself is the best source of such information, this gives industry a degree of leverage over regulatory arrangements which, in the extreme case, might lead to capture. From this follows that capture problems might be of particular relevance for the regulatory standards approach. The risk that regulatory rules primarily serve the interests of the industry also applies to private self-regulation where similar information asymmetries between the self-regulatory bodies and public enforcers exist(6). The potential for capture on the European level is lower if regulation is based on the definition of broad objectives and hence requires no detailed technical information on the side of the EU regulator. This constellation characterises new instruments and the OMC. However, a low potential for capture at the European level does not exclude selective access of certain private interests during the implementation stage. Thus, the danger of capture is crucially dependent on the domestic arrangement which vary from country to country.

The level of discretion is also of relevance when accounting for the context responsiveness of different regulatory approaches. Leeway for implementers in adjusting to regulatory requirements in light of distinctive problem constellations at the national, regional or local levels enhances the chances for effective problem-solving. The realisation of this potential, however, requires steering mechanisms which ensure that discretion is used in line with the overall objectives of the regulation, hence, rely on the modification and stimulation of the policy context in favour of effective compliance. Both requirements (high discretion, responsive steering mechanisms) are given in the cases of new instruments and the OMC.

At the same time, however, these features of new instruments and the OMC, imply certain disadvantages with respect to the predictability of regulatory outcomes. Thus, it is rather difficult to estimate, if and to what extent changes in domestic incentive structures might actually result in desired behavioural changes and political results (cf. Knill and Lenschow 2000). The same problem applies to the stimulation of mutual learning and coordination across national policy-makers. Considering these uncertainties and the broad leeway in terms of substantive objectives, both highly discretionary regulatory approaches achieve a poor ranking on predictability. The opposite holds for regulatory standards and private self-regulation, where clear substantive objectives provide a sounder basis for predicting results.(7)

\subsection{Democratic Legitimacy}

Ever since the rather unexpected opposition to the Maastricht Treaty frequent reference is made to a democratic deficit built into the EU polity. This lack of democracy is usually associated with weak parliamentary influence in and control over policy making in the multi-level system. Shortcomings of representative democracy have not been balanced by opportunities for public participation in the political process. Executive bias, secrecy, intransparency and inequality have become keywords in describing decision-making processes in the Council. Although the Council largely follows consensual practices, avoiding the outvoting of significant minorities, secrecy coupled with the formal option of majority voting have created a climate of distrust in the population. This is all the more significant as past integrative efforts have not (yet) resulted in the creation of a truly European public sphere feeding a transboundary political discourse and to push for the societies' input in EU policy making. In other words, the very foundation of a functioning European democracy continues to be underdeveloped.

The transformation of the regulatory modes we are analysing in this chapter partly reflects a response to this perceived lack in "input legitimacy". Non-traditional regulatory instruments aim at gaining public acceptance through better communication with the addressees, higher responsiveness to national or regional problems and the invitation of public control. We see a trend toward decentralising regulatory responsibilities to national and regional authorities and therefore a certain re-empowerment of national legislatures. 
Before turning to the democratic performance of the different regulatory modes in more detail, we need to shed some light on the interplay of democratic norms and structures in the EU. Generally, we can distinguish between three democratic models aiming to aggregate the public will in accordance with full and equal representation of the people. Depending on the existence of deep cleavages in society (tending to a polarisation of opinions in the public) and the presence and depth of general solidarity in the political entity (leading to more or less acceptance of a potential minority status), we have seen the evolution of two types of representative democracies - majoritarian and consensual which are distinct in their relative protection of functional and territorial minorities (cf. Lijphart 1984). Furthermore, territorial scope and functional differentiation of the modern state and the rising demands on elected officials have contributed to the emergence of the associational format (cf. Cohen and Rogers 1995) where interest associations assume political functions and, due to their proximity to the public ear, contribute to enhance the sovereignty of the people(8).

In the EU, we see a combination of all three models: Policy making within the majoritarian model is based on the support of a majority in the population. In the EU, the European Parliament representing the European public at large is directly elected by all citizens of the member states and operates on the basis of majority voting. However, the standard of equal representation has been altered in favour of minority protection by giving the electorate from small member states additional weight. The Council of Ministers derives its democratic legitimacy indirectly from national elections and is dominated by consensual norms. Traditionally, these have been clearly visible in the requirement of unanimity voting in politically salient questions and the need for rather strong majorities otherwise; in addition, small states are protected by the present arrangement of weighed votes. Increasingly, we see Council negotiations also influenced by majoritarian patterns, however, strengthened in all Treaty amendments since the mid-80s. Finally, associational arrangements have entered into EU policy making practices (Eising 2001, Schmalz-Bruns 1997).(9) At the stage of policy formulation particularly the Commission relies heavily on the input of various interest groups (Eising and Kohler-Koch 1994, Greenwood and Aspinwall 1998). More crucially, certain decisionmaking responsibilities have been conferred to interest associations. For instance, private organisations lead the process of technical harmonisation and norm setting in the fields of social and environmental policy (Eichener and Voelzkow 1994), corporatist structures have been introduced in the regulation of industrial relations (Falkner 2000) and we see experiments with industrial selfregulation.

This mix of procedures and the interplay between the two representative institutions and interest associations fails to fully match any conventional democratic quality standard. From the perspective of the majoritarian model, the criterion of equality is violated and the EP does not carry enough weight in decision making; advocates of the consensus model will emphasize the non-existence of a European public glued together by a shared identity and trans-national solidarity and hence consider any majoritarian processes premature. Both schools are likely to be critical with respect to patterns of democratic control in the EU, pointing to limitations in parliamentary oversight, judicial review and direct scrutiny (cf. Baldwin and Cave 1999, 152-3). Associational democracy is usually perceived as a complementary model to the conventional structures of democratic representation, shifting some responsibility from the state to the people while maintaining a framework for equal representation and control. Considering the potential distance of EU institutions from the people, associational structures have been perceived as a chance to involve the public more directly in policy making, to close conflictual gaps in society and create a European public sphere; the ability to ensure equality and democratic control at the same time is viewed more critically. 
On the basis of this brief discussion we can formulate three assumptions that will guide the following more detailed review of the democratic quality of the different regulatory modes in EU policy making:

- A1. Due to the deep national cleavages characterising the EU polity, the absence of a selfperceived "European demos" and in light of future enlargements, we consider the consensus model of democracy more adequate than the majoritarian model (cf. Kielmansegg 1996).

- A2. The democratic legitimacy of associational decision making processes depends on representative structures and practices internally and its embeddedness in conventional structures of representative democracy (cf. Cohen and Rogers, 1995, 69-71).

- A3. We consider the democratic legitimacy of national structures generally as superior to that of within the EU multi-level governance system

Turning now to the evaluation of the four regulatory modes, we disaggregate the criterion "democratic legitimacy" in three sub-criteria: public mandate, due process and accountability. These sub-criteria capture the nature of the demos' input across all phases of policy making - from policy formulation to implementation and evaluation - and hence offer a full view of the democratic process.

\section{Public Mandate}

In evaluating the quality of the public mandate, we will first analyze the dominant democratic model underlying each regulatory type and link this analysis to the discussion above. Second, we look at the impact of multi-level decision-making on the democratic legitimacy.

The four modes of regulatory policy claim legitimacy on the basis of different procedures to establish the public mandate: Notwithstanding the associative input indicated above, regulatory standards and new instruments are primarily based on a mix of majoritarian and consensual forms of representative authorisation. OMC relies at the decision making stage merely on the consensus model, with some input of stakeholder representatives. Self-regulation, in turn, is based on the associational model.

Considering the societal structure of the EU, we consider the democratic mandate for OMC guidelines and benchmarks least problematic (cf. A1), although we need to acknowledge that the national representatives in the Council act at considerable distance from public discourses and, despite consultation arrangements with the EP and "stakeholders", are vulnerable to develop an executive bias. The mandate for regulatory standards and new instruments is based on mixed patterns. The required majority in the Council under the qualified majority rule is high and Council decision making remains influenced by consensual and reciprocity norms. Nevertheless, we witness a gradual shift towards majoritarian decision making procedures which is problematic from a democratic angle. The critical issue in the case of self-regulation consists in the decision to delegate regulatory power to private actors. A democratic mandate for such a decision needs to be derived from conventional practices of representative democracy $(\underline{\mathrm{A} 2})$. In this respect the self-regulatory practices in the EU tend to be only indirectly legitimised as most of them are initiated by the European Commission and hence, the result of an administrative decision.(10) An exception is the Social Dialogue, which is based on a Treaty provision and framed by representative regulatory policy making on the EU level in the sense that the proposal of the social partners needs to be agreed by Council and Parliament before being adopted as an EU directive. Here associative practices complement and potentially strengthen EU decision making procedures by bridging distant EU institutions and society (cf. Falkner et al. 2002).

Considering the multi-level structure of EU regulatory policy making, those forms of regulatory 
interventions that build on the democratic structures in the member states possess a clear(er) public mandate. Hence, the two subsidiarity models have a structural advantage vis-à-vis regulatory standards and self-regulation. (cf. A3). OMC relies on national governments or legislatures to formulate and decide all concrete policy measures aiming to achieve the benchmarks set on the EU level. In contrast, new instruments seek national democratic mandates merely for the specification and sometimes elaboration of EU law. Nevertheless, especially framework legislation leaves real scope for national decision making and exploits the democratic potential of subsidiarity.(11)

To sum up, the consensual style of decision making on the EU level combined with the most discretionary practice places OMC at "first place", followed by discretionary new instruments. Notably, OMC acknowledges the absence of a European demos while at the same time aiming at building a European public sphere, although at the expense of European parliamentary input. Selfregulatory practices, bypassing any representative organ on the EU-level, rank even below the regulatory standards relying on these organs. However, there may be variants that are backed legally (Treaty mandates) and embedded in EU law. These pass as a legitimate form of associative democracy while at the same time closing the gap between the EU and society.

\section{Due Process}

Due process relates to the decision making and the implementation phase of public policy making and claims public support on the basis of equal and wide participatory rights granted to as well as substantive equality provided for those affected by regulatory decisions. Both dimensions are especially challenging in the trans-national and multi-level system of the EU.

The issue of participatory rights is distinct from the public mandate in that it refers to the scope of participation in the formulation of regulatory policy by those affected or involved in the implementation. Here, we are confronted with two opposing general images of conventional regulatory policy making in the EU: While some emphasise the extraordinary openness of the Commission, inviting input from all parts of society, others perceive the Commission as a gatekeeper and deplore the level of executive and bureaucratic discretion leading to potential biases in the public input and even to forms of clientelism. Intransparency is a main criticism put forward against the rise of committee-driven policy formulation (as well as decision making and implementation). While equal access of all interests affected remains an empirical question, intransparency generally hinders effective insurance of due process inside comitology.(12)

The delegation of regulatory responsibilities to private actors or to the member state level, adds new dimensions to due process. Again, we will assume that all democratic standards are met on the national level. But furthermore, we can observe that the EU puts a lot of effort in designing and prescribing due process procedures for implementation and subsequent regulation in the member states. New instruments such as procedural rights to information or public hearings aim to enhance public involvement on the ground. OMC resembles new instruments in encouraging "enlightened" policy making on the EU and national level through incentive structures and participatory practices.

In contrast to all forms of public regulation, it is the very point of self-regulation to closely involve those affected by the regulation; but in practice, this has come at the risk of turning "due process" on its head. Only to the extent that all those affected by the regulation (or non-regulation) in the relevant problem area are represented in the self-regulatory process, such "private governance" meets due process standards. The proverbial characteristic of self-regulation is its industrial bias, however, constraining the input of the general public, the consumers, the residents etc. This bias is related to the desire to form a coherent group, sharing similar problems and pressures, in order to arrive at a 
solution before the dog - in the form of the EU regulator - bites. Of course, the ECJ operates as a watchdog and self-regulatory systems can be structured inclusively from the start (recall $\underline{\mathrm{A} 3}$ ).

With respect to the second dimension of due process, substantive equality, the much praised regulatory discretion may turn out to be a problem. Discretion opens room for unequal substantive treatment of the regulated, inconsistencies within or between policies and distortions of the market due to different local regulatory patterns. On the basis of substantive equal treatment therefore, EU public or private standard setting appears superior to the two subsidiarity models, although the capacity of the EU regulators to ensure that self-regulatory networks guarantee the application of the private norms is also limited. The insistence on substantive equality is not uncontroversial, however, as it may go hand in hand with a great insensitivity to the circumstances experienced by those affected by regulatory decisions. Uniform regulation does not take account of different administrative structures, established technologies or problem saliencies. Hence we need to distinguish between regulatory content that requires uniform application in the EU due to the presence of trans-boundary effects or market distortions and regulatory content that can be achieved flexibly. The combination of regulatory uniformity and discretion is the main philosophy of new instruments. The recognition of national diversity also explains the high discretionary practice of OMC. However, while OMC aims to facilitate learning and public involvement, hoping for national improvements and in the longer run more consistent regulatory structures in the EU in areas where EU-regulation is absent, it does not establish any firm regulatory framework guaranteeing activity on the national or regional level.

To sum up the discussion on due process, on two dimensions we saw ambiguous effects. While regulatory discretion is likely to impact positively on the level of access and participation of those affected by the decisions (especially the implementing actors), discretion does not contribute to substantive equality. The relative importance of this latter criterion varies with the regulatory intent, however. With respect to the dominant steering mechanisms we see two patterns of making use of associative structures. The coercive model contributes to substantive equality, while treating the openness of procedures and involvement of stakeholders as secondary; the learning model emphasises openness of the process more than equal outcomes. From this ambiguous picture new instruments stand out as performing quite well on all counts.

\section{Accountability}

Regulators may claim democratic legitimacy even in cases where the public has not been involved in the rule making process if the people have the possibility to exercise public control over the responsible regulatory authority. Once again, we need to take into consideration the multi-level structure of the European Union. Focusing on Brussels, Baldwin and Cave (1999, 152-3) arrive at generally sceptical conclusions, pointing to a gap between the powers conferred to the Community and the controls of the elected Parliament, the weak control most national parliaments have over their governments acting on the European arena - a situation made worse by the fact that the citizens of a member state may be regulated by a provision that their representing minister has been outvoted on. Also, they observe that the ECJ's resources are limited; review tends to be sporadic and depends on there being a party with the knowledge and financing to bring on action. Furthermore, the ECJ looks to the legality, not merits or substance, of regulatory rules or actions. This perspective applies to the classical form of regulatory intervention, namely EU regulatory standards.

Both parliamentary and direct public control are enhanced by the decentralisation of regulatory tasks to regional or national public authorities (cf. A3), hence the use of discretionary new instruments. The fact that in practice this may come at the expense of some confusion over the relevant locus of 
responsibility does not negate their potential to facilitate a higher level of control in a multi-level system. In the case of OMC this benefit of subsidiarity is taken even further as national parliamentary and electoral control mechanisms apply to the bulk of the regulatory activity. Furthermore, OMC attempts to compensate for intransparent structures on the EU-level with soft methods of accountability like peer review and reporting requirements, combined with a high level of publicity, aiming to ensure that member state governments meet the common benchmarks. The process of benchmarking on the EU-level, establishing the framework for national policy making, requires closer analysis. On the one hand, this process seems to escape the - even though deficient traditional forms of control in Brussels, making bad things worse. The European Parliament is largely excluded from the process; judicial review is secondary due to the weak legal context.(13) On the other hand, the consensual structure (cf. A1) and participation of stakeholders links the benchmarking process to national parliaments and the associative representatives of the general public, creating alternative ways towards public control.

Finally, self-regulation is clearly most problematic in terms of public control. Besides the remote sanctioning powers of public authorities, self-regulatory systems risk being captured by groups who are not representative of the general public - or even those affected by the regulation - and closed to public oversight. This does not mean that self-regulatory systems principally cannot be held accountable. To the extent that they are constrained by statutory prescriptions, ministerial or parliamentary guidelines, reporting and publication requirements, etc. self-regulators become subject to public control and scrutiny (cf. A2). The implicit threat of legislative intervention in case of selfregulatory failure may have a similar effect.

The following table summarises the preceding discussion. While a summarising score is impossible given the complexity of the issue, we observe generally good performance in the two subsidiarity models, due to their reliance on national democratic structures and a partial opening of decision making procedures to the wider public, paving the ground for an emerging European public sphere.

\section{Table 4}

\section{Conclusion $^{\uparrow}$}

Although methodological problems make it impossible to establish an overall ranking of the different modes of European regulation in terms of their governance performance, the comparatively good evaluation of new instruments and OMC is somewhat surprising. The question that immediately emerges is "Why are regulatory standards the still dominating mode of intervention in EU policy making?" In this context several factors have to be emphasised.

First, the dominance of the classical approach might partly be the result of institutional inertia preventing most organisations to engage in quick and radical reforms and the structural limits of the EU regulatory state in tying the levels of governance into an effective whole.

Second, it should not be overlooked that the choice of evaluation criteria is somewhat selective. Although we have focused on the most common factors, we can hardly claim that our selection is encompassing all aspects which might be of relevance. Thus, it might well be the case that in selecting different criteria, one might arrive at different evaluation results. This holds true, in particular, for OMC, which has number of limitations potentially reducing its regulatory utility: (a) Both, its regulatory claim (to merely establish guidelines and benchmarks) and the consensual decision making process may result in an undemanding framework for national policy making. Hence, there may be a trade-off between democratic decision making and reliable steering capacity. 
(b) Effective implementation is made dependent on internal learning processes and therefore cannot be expected immediately. (c) OMC relies on an experimental process of problem solving, hence is not designed to ensure certain results. (d) OMC accepts the unequal treatment of regulatory addressees in the member states; i.e. is not interested in creating a level playing field.

Third, the choice of regulatory approaches is rarely the result of a necessarily selective normative evaluation on the part of the policy makers, but it reflects underlying interest constellations and strategic interactions shaping the decision-making processes at the European and national level. From this perspective, both new instruments and OMC constitute rather unsuitable approaches if the creation of a level playing field and hence, harmonisation is one of the aims of the regulators. Such aim would be best served through hierarchical regulatory standards. The same holds true if the decision makers share a preference for predictable and reliable regulatory arrangements. The regulatory framework of $\mathrm{OMC}$ and new instruments is likely to be too flexible, whereas hierarchical norms give clearly defined directions. As the dominance of classical approaches suggests, these considerations have obviously been of crucial importance in EU governance.

However, this does not imply an inevitable dominance of the regulatory standards approach. Both new instruments and OMC could be preferable options if the maintenance of national diversity is desirable or unchangeable. The same holds for constellations in which risk and insecurity are characterising the regulatory context with the effect that no clear and generally applicable regulatory solution is in supply.

In sum, we come to the general conclusion that any final evaluation of a regulatory format depends on the weighing of the individual criteria, which in turn needs to be based on the character of the policy problem to be solved. While regional diversity, and hence a discretionary policy design may be perfectly acceptable in some areas, the economic context (competition, mobility, etc.), the presence of external and in particular transnational effects, the expressed pursuit of shared values or the commonly perceived problem salience may call for uniform standards or procedures in all member states. It was the intent of this paper to develop a template that will facilitate any such contextualised evaluation. We have provided criteria and an overview of structural advantages and disadvantages; the weighing of the criteria needs to be done on a case by case basis. Finally, it should be noted that our analysis can be used not only to decide between regulatory modes, but also to engage in regulatory reforms within a certain mode.

\section{References $^{\top}$}

Abromeit, H. (1998). Ein Vorschlag zur Demokratisierung des europäischen Entscheidungssystems. in: Kohler-Koch, B. (ed.): Regieren in entgrenzten Räumen. PVS Sonderheft 29/1998. Opladen: Westdeutscher Verlag, 80- 90.

Baldwin, R./ Cave, M. (1999).Understanding Regulation: Theory, Strategy, and Practice. Oxford: Oxford University Press.

Baldwin, R. (1995). Rules and Government. Oxford: Oxford University Press.

Benz, A. (1998). Politikverflechtung und Politikverflechtungsfalle. Koordination und Strukturdynamik im europäischen Mehrebenensystem. in: Kohler-Koch, B. (ed.): Regieren in entgrenzten Räumen. PVS Sonderheft 29/1998. Opladen: Westdeutscher Verlag, 558- 589. 
Berman, Paul (1980). Thinking About Programmed and Adaptive Implementation: Matching Strategies to Situations. in: Ingram, H./Mann, D. (eds.). Why Policies Succeed or Fail. London: Sage, 205-27.

Black, J. M. (1996). Constitutionalising Self- Regulation. Modern Law Review 59, 24- 55.

Cohen, J./Rogers J. (1995) Secondary associations and democratic governance. In: Cohen J./Rogers J. (eds.) Associations and Democracy. London: Verso, 236-267.

Cohn, M. (2002). Fuzzy Legality in Regulation: The Legislative Mandate Revisited. Law and Policy 23, 469-497.

De la Porte, C./ P. Pochet (eds.) (2002). Building Social Europe through the Open Method of Coordination. Brussels: P.I.E. - Peter Lang.

Eichener, V./Voelzkow, H. (1994). Europäische Integration und verbandliche Interessenvermittlung. Marburg: Metropolis Verlag.

Eising, R. (2001). Assoziative Demokratie in der europäischen Union? In: Zimmer, A./ Wessels, B. (ed.), Verbände und Demokratie in Deutschland. Opladen: Leske + Budrich, 293-329.

Eising, R./Kohler-Koch, B. (1994). Inflation und Zerfaserung: Trends der Interessenvermittlung in der Europäischen Gemeinschaft. in: Streeck, W. (ed.), Staat und Verbände. PVS Sonderheft 25/1994, Opladen: Westdeutscher Verlag, 175-206.

Falkner, G. (2000). Problemlösungsfähigkeit im europäischen Mehrebenensystem: Die soziale Dimension. in: Grande, E./Jachtenfuchs, M. (eds.), Wie problemlösungsfähig ist die EU? Regieren im europäischen Mehrebenensystem. Baden-Baden: Nomos, 283-311.

Falkner, G./Hartlapp M./Leiber, S./Treib, O. (2002). Democracy, Social Dialogue and Citizenship in the European Multi-level System. Paper presented at the 1st Pan-European Conference on European Union Politics, "The Politics of European Integration: Academic Acquis and Future Challenges", Bordeaux, 26-28 September.

Gunningham, N./Rees, J. (1997). Industry Self-Regulation: An Institutionalist Perspective. Law and Policy 19 (4).

Greenwood, J./Aspinwall, M. (eds.) (1998). Collective Action in the European Union. London: Routledge.

Héritier, A. (1999). Policy-Making and Diversity in Europe: Escape from Deadlock. Cambridge: Cambridge University Press.

Héritier, A. (2002). New Modes of Governance in Europe: Policy Making Without Legislating? in: Héritier, A. (ed.). The Provision of Common Goods: Governance across Multiple Arenas. Boulder: Rowman \& Littlefield, 185-206.

Héritier, A./Knill, C./Mingers, S. (1996). Ringing the Changes in Europe. Regulatory Competition and the Transformation of the State. Berlin: de Gruyter.

Hodson, D./ Maher I. (2001) The Open Method as a New Mode of Governance. Journal of Common Market Studies 39 (4), 719-746.

Holzinger K. (2001). Aggregation Technology of Common Goods and its Strategic Consequences. 
Global Warming, Biodiversity and Siting Conflicts. European Journal of Political Research, 40, 117-138.

Holzinger, K./ Knill, C./ Schäfer, A. (2003), Steuerungswandel in der europäischen Umweltpolitik? In: Holzinger, K./Knill, C./Lehmkuhl, D. (eds.), Politische Steuerung im Wandel: Der Einfluss von Ideen und Problemstrukturen. Opladen: Leske + Budrich.

Joerges, C. (2002). Deliberative Supranationalism - Two Defences. European Law Journal 8 (1), $133-151$

Kielmansegg, P. Graf (1996) Integration und Demokratie. In: Jachtenfuchs, M./Kohler-Koch, B. (eds.) Europäische Integration. Opladen: Leske + Budrich, 47-72

Knill, C./ Héritier, A. (1996). Neue Instrumente in der europäischen Umweltpolitik: Strategien für eine effektivere Implementation. In: Gertrude Lübbe-Wolff (ed.), Der Vollzug des europäischen Umweltrechts. Berlin: Erich Schmidt Verlag, 209-234.

Knill, C./Lenschow, A. (eds.), (2000). Implementing EU Environmental Policy: New Directions and Old Problems. Manchester: Manchester University Press.

Krämer, L. (1992). Focus on European Environmental Law. London, Sweet \& Maxwell.

Lijphart, A. (1984). Democracies. Patterns of majoritarian and consensus government in twenty-one countries. New Haven: Yale University Press.

Lipsky, M. (1980). Street-Level Bureaucracy. New York: Russell Sage.

Lübbe-Wolff, G. (1996). Stand und Instrumente der Implementation des Umweltrechts in Deutschland. in: Lübbe-Wolff, G. (ed.) Der Vollzug des europäischen Umweltrechts. Berlin: Erich Schmidt Verlag, 77-106.

Majone, G. (1994). The rise of the regulatory state in Europe. West European Politics 17 (3), 77 101.

McBarnet, D./ Whelan, C. (1991). The Elusive Spirit of the Law: Formalism and the Struggle of Legal Control. Modern Law Review 54.

Mitnick, B. (1980). The Political Economy of Regulation. New York.

Moran, M. (2002). Review Article: Understanding the Regulatory State. British Journal of Political Science 32, 391- 413.

Ogus, A. (1995). Rethinking Self- Regulation. Oxford Journal of Legal Studies 15 (97).

Scott, C. (forthcoming in 2003). The (Post-) Regulatory State. In: Jordana, J./Levi-Faur, D. (eds) The Politics of Regulation: Examining Regulatory Institutions and Instruments in the Age of Governance. London: Edward Elgar.

Scott, J./Trubek, D. M. (2002). Mind the Gap: Law and New Approaches to Governance in the European Union. European Law Journal 8 (1), 1- 18.

Scharpf, F. (1997). Games Real Actors Play: Actor-Centered Institutionalism in Policy Analysis. Boulder: Westview Press. 
Scharpf, F. (1999). Governing in Europe: Effective and Democratic? Oxford: Oxford University Press.

Schmalz-Bruns, R. (1997). Bürgergesellschaftliche Politik - ein Modell der Demokratisierung der europäischen Union? In: Wolf, K.-D. (ed.). Projekt Europa im Übergang. Baden-Baden: Nomos, 6390 .

Working Group (2001) European Commission: Involving Experts in the Process of National Policy Convergence. Report by Working Group 4a, June.

http://europa.eu.int/comm/governance/areas/group8/report_en.pdf

Zürn, M. (1996). Über den Staat und die Demokratie im europäischen Mehrebenensystem. Politische Vierteljahresschrift 37, 27-55.

\section{Endnotes ${ }^{\top}$}

(*) This article will be published in a slightly revised form in Jacint Jordana and David Levi-Faur (eds.), The Politics of Regulation: Examining Regulatory Institutions and Instruments in the Age of Governance. London: Edward Elgar, 2003. We would like to thank two anonymous referees for very instructive and helpful comments.

(1) Compare Moran (2002) for an excellent review as well as Scott (2003).

(2) The distinctive form of EU legislation (e.g. the directly applicable Regulations or Directives requiring national transposition) has no systematic impact on the discretion level. Empirical research indicates that Directives are often formulated in a highly detailed manner, hence leaving little room for adjustments in national transposition laws. In addition, the Court emphasised that Directives, even without national transposition, unfold direct legal effects at the national level. On the other hand, there are Regulations which are formulated broadly, leaving the member states considerable leeway for interpreting the directly binding requirements.

(3) Also self-regulation and OMC are new forms of governance but distinct from the so-called new instruments in their more radical departure from traditional law-based patterns of intervention.

(4) To be sure, judging the extent to which a certain mode of regulation is legitimate in terms of input and output criteria is not to offer an assessment of the actual support that a regulator enjoys. It is rather an assessment of the legitimacy that a regulator deserves. What matters is the collective justificatory power of the arguments that can be made with respect to the four criteria in question (cf. Baldwin and Cave 1999, 82).

(5) In some contexts, the comitology procedure provides for an alternative to lengthy legislative negotiations and allows for faster adjustment to typically technological or scientific developments.

(6) The problem of capture will generally be much more pronounced in cases where public interests (such as environmental or consumer organisation) are excluded from the decision-making process.

(7) Of course, even the predictability of outcomes of clear regulatory standards is limited in many problem areas that are characterised by high levels of scientific uncertainty and hence, risk.

(8) This, of course, depends on the internal organisational characteristics of interest associations as well as the level to which associative constellations succeed in representing the plurality of public opinion. 
(9) Furthermore, the mode of direct democracy exists in the EU - however, only with regard to constitutional questions and not in the process of regulatory policy making. Hence, we can ignore this democratic form in our discussion.

(10) The Commission receives its mandate from democratically legitimated institutions - Council and Parliament - who delegate certain tasks to it, and from the provisions of the EU Treaty.

(11) In the regulatory practice of the EU, framework legislation tends to be coupled with the drafting of more detailed daughter directives, however, leaving the regulatory responsibility with policy makers in Brussels.

(12) It must be noted that committees do not exist outside legal oversight (cf. Comitology Decision $87 / 373 /$ EEC) and therefore, may also contribute to the rationalisation of regulatory processes and the creation of mutually agreeable and cooperative solutions (cf. Joerges 2002).

(13) Some, though not all, forms of national policy coordination have been introduced directly to the Treaties, however in very generic terms. Besides, OMC benchmarks or guidelines are not legally binding (Working Group 2001) 


\section{Table I}

\section{Modes of Regulation in the EU}

\begin{tabular}{|l|l|l||}
\hline \multicolumn{1}{|l||}{} & High level of obligation & Low level of obligation \\
\hline $\begin{array}{l}\text { High level of } \\
\text { discretion }\end{array}$ & $\begin{array}{l}\text { New Instruments } \\
\text { economic, communicative, framework } \\
\text { regulation }\end{array}$ & $\begin{array}{l}\text { OMC } \\
\text { Open method of } \\
\text { coordination }\end{array}$ \\
\hline $\begin{array}{l}\text { Low level of } \\
\text { discretion }\end{array}$ & $\begin{array}{l}\text { Regulatory Standards } \\
\text { substantive, procedural }\end{array}$ & $\begin{array}{l}\text { Self-regulation } \\
\text { in the shadow of the state }\end{array}$ \\
\hline
\end{tabular}

\section{Table II}

\section{Steering Mechanisms and Types of Regulation}

\begin{tabular}{|c|c|c|c|c|}
\hline & $\begin{array}{l}\text { Regulatory } \\
\text { Standards }\end{array}$ & New Instruments & Self-regulation & OMC \\
\hline Coercion & $\begin{array}{l}++ \\
\text { legally binding } \\
\text { standards }\end{array}$ & $\begin{array}{l}+ \\
\text { framework and } \\
\text { procedural rules }\end{array}$ & $\begin{array}{l}+ \\
\text { shadow of hierarchy }\end{array}$ & $\begin{array}{l}+ \\
\text { reporting and } \\
\text { monitoring }\end{array}$ \\
\hline $\begin{array}{l}\text { Incentive } \\
\text { structures }\end{array}$ & 0 & \begin{tabular}{|l}
++ \\
changes of procedural \\
and/or material \\
opportunities
\end{tabular} & $\begin{array}{l}++ \\
\text { private actors influence } \\
\text { regulatory standards }\end{array}$ & $\mid \begin{array}{l}+ \\
\text { peer pressure }\end{array}$ \\
\hline \multirow[t]{2}{*}{ Learning } & 0 & 0 & $\begin{array}{l}+ \\
\text { communication in } \\
\text { private networks }\end{array}$ & $\begin{array}{l}++ \\
\text { best practice } \\
\text { models }\end{array}$ \\
\hline & $\begin{array}{l}\text { Hierarchy } \\
\text { model: } \\
\text { power of } \\
\text { coercion }\end{array}$ & $\begin{array}{l}\text { Public delegation } \\
\text { model: } \\
\text { traditional } \\
\text { subsidiarity }\end{array}$ & $\begin{array}{c}\text { Private delegation } \\
\text { model }\end{array}$ & \begin{tabular}{|c|} 
Radical \\
subsidiarity \\
model: \\
public learning \\
approach
\end{tabular} \\
\hline
\end{tabular}

Legend: ++ dominant mechanism; + relevant mechanism; 0 irrelevant mechanism 


\section{Table III}

\section{Regulatory Modes and Problem-solving Capacity}

\begin{tabular}{|c|c|c|c|c|}
\hline & $\begin{array}{l}\text { Regulatory } \\
\text { Standards } \\
\end{array}$ & New Instruments & $\begin{array}{c}\text { Self- } \\
\text { regulation }\end{array}$ & OMC \\
\hline \begin{tabular}{|l|} 
Adjustment \\
flexibility \\
\end{tabular} & Low & Low & High & High \\
\hline Danger of capture & High & $\begin{array}{c}\text { Low, but depending on } \\
\text { national transposition }\end{array}$ & High & $\begin{array}{l}\text { Low, but depending on } \\
\text { national transposition }\end{array}$ \\
\hline \begin{tabular}{|l|} 
Context \\
responsiveness \\
\end{tabular} & Low & High & Low & High \\
\hline $\begin{array}{l}\text { Predictability of } \\
\text { outcomes }\end{array}$ & High & Low & High & Low \\
\hline
\end{tabular}

\section{Table IV}

\section{Democratic legitimacy of four regulatory modes}

\begin{tabular}{|c|c|c|c|c|}
\hline & $\begin{array}{l}\text { Regulatory } \\
\text { Standards } \\
\end{array}$ & New Instruments & Self-regulation & OMC \\
\hline \multirow{2}{*}{$\begin{array}{l}\text { Democratic } \\
\text { Mandate }\end{array}$} & $\begin{array}{l}\text { EU level: } \\
\text { deficient }\end{array}$ & $\mid$\begin{tabular}{|l} 
EU-level: \\
deficient
\end{tabular} & \begin{tabular}{|l} 
EU-level: \\
mostly poor
\end{tabular} & EU-level : \\
\hline & & $\begin{array}{l}\text { National level: } \\
\text { good }\end{array}$ & $\begin{array}{l}\text { SR-level: } \\
\text { typically biased }\end{array}$ & 吕ional level: \\
\hline \multirow[b]{2}{*}{ Due Process } & $\begin{array}{l}\text { Participation } \\
\text { at the discretion } \\
\text { of the EU } \\
\text { executive }\end{array}$ & $\begin{array}{l}\text { Participation } \\
\text { on EU-level as RS; } \\
\text { emphasised on } \\
\text { national level }\end{array}$ & \begin{tabular}{|l} 
Participation \\
great reliance on \\
"those affected", \\
but danger of bias \\
\end{tabular} & \begin{tabular}{|l} 
Participation \\
stakeholder \\
participation on both \\
levels of governance
\end{tabular} \\
\hline & $\begin{array}{l}\text { Substantive } \\
\text { equality } \\
\text { yes - } \\
\text { disregarding } \\
\text { local } \\
\text { circumstances }\end{array}$ & \begin{tabular}{|l} 
Substantive \\
Equality \\
partial - combined \\
with \\
responsiveness to \\
local conditions
\end{tabular} & \begin{tabular}{|l} 
Substantive \\
Equality \\
yes - assuming \\
authority of self- \\
regulatory network \\
vis-à-vis its \\
members \\
\end{tabular} & \begin{tabular}{|l} 
Substantive Equality \\
weak - indirect \\
encouragement of \\
local adjustments
\end{tabular} \\
\hline Accountability & $\begin{array}{l}\text { Control } \\
\text { deficient on EU } \\
\text { level }\end{array}$ & $\begin{array}{l}\text { Control } \\
\text { deficiency on EU- } \\
\text { level is partly } \\
\text { corrected on } \\
\text { national level }\end{array}$ & $\begin{array}{l}\text { Control } \\
\text { weak in practice, } \\
\text { but possible in } \\
\text { theory }\end{array}$ & $\begin{array}{l}\text { Control } \\
\text { ambiguous on EU } \\
\text { level; traditional + soft } \\
\text { mechanisms applied } \\
\text { to national activity }\end{array}$ \\
\hline
\end{tabular}

